\title{
Light-dependent uptake, translocation and foliar release of phosphorus by the intertidal seagrass Zostera noltii Hornem.
}

\author{
J.L. Pérez-Lloréns ${ }^{\mathrm{a}}$, P. de Visscher ${ }^{\mathrm{b}}$, P.H. Nienhuis ${ }^{\mathrm{b}}$ and F.X. Niell ${ }^{\mathrm{c}}$ \\ ${ }^{a}$ Departamento de Biologia, Facultad de Ciencias del Mar, Universidad de Cádiz, Cádiz, Spain; ${ }^{\mathrm{b}}$ Netherlands \\ Institute of Ecology, Yerseke. The Netherlands; ${ }^{\circ}$ Departamento de Ecologia, Facultad de Ciencias, \\ Universidad de Málaga, Málaga, Spain
}

(Received 5 May 1992; revision received 21 September 1992; accepted 24 September 1992)

\begin{abstract}
Light-dependent $P$ uptake by root-rhizomes, acropetal translocation and subsequent foliar release by Zostera noltii Hornem. was studied under laboratory conditions in two-compartment chambers using ${ }^{32} \mathrm{P}$. The uptake by underground parts was unaffected by light conditions but the acropetal translocation proceeded more rapidly in light than in dark, indicating a coupling to the metabolic activity of the plants. The translocated $P$ was mainly accumulated in the youngest leaves $(30 \%)$, i.e., the most actively growing parts. Foliar release of $\mathrm{P}$ might be considered negligible (2-4\% of the $\mathrm{P}$ taken up by root-rhizomes), indicating that the role of $Z$. noltii as a "P pump" is of minor importance in the cycling of $P$ between sediment and water. This was calculated for part of the Oosterschelde estuary, Zeeland, The Netherlands.
\end{abstract}

Key words: Light effect; P accumulation; Release; Translocation; Uptake; Zostera noltii

\section{INTRODUCTION}

Although the seagrass Zostera noltii Hornem. occurs along the coasts of western Europe (Den Hartog, 1970; Jacobs, 1982), forming large stands in the intertidal (and subtidal) zone, little work has been devoted to study the ecophysiology of this species, especially its role in the cycling of $P$ between sediment and water. The main focus of the research carried out in $Z$. noltii, was towards the abundance of macrozoobenthos (Jacobs \& Huisman, 1982; Jacobs et al., 1982), growth and seasonal dynamics (Jacobs et al., 1983; Pérez \& Camp, 1986; Vermaat et al., 1987; Pérez, 1989; Pérez-Lloréns, 1991), photosynthetic behaviour (Jiménez et al., 1987, 1991; Pérez-Lloréns, 1991) and internal nutrient content (Delgado, 1985; Pirc \& Wollenweber, 1988; Pérez-Lloréns \& Niell, 1989; Pérez-Lloréns et al., 1991).

$Z$. noltii, as others submerged aquatic angiosperms, is capable of taking up P from the surrounding water by the leaves as well as by the root-rhizomes from the interstitial water of the sediment. Presumably, the sediment is the principal source of phosphate

Correspondence address: J.L. Pérez-Lloréns, Departamento de Biología, Facultad de Ciencias del Mar, Universidad de Cádiz, 11510 Puerto Real, Cádiz, Spain

Publication no. 630 Netherlands Institute of Ecology, Centre for Estuarine and Coastal Ecology, Yerseke, The Netherlands. 
but the relative concentrations of phosphate in the water and sediment determine the main site for uptake (McRoy \& Barsdate, 1970; Bristow \& Whitecombe, 1971; Denny, 1972; McRoy et al., 1972; Patriquin, 1972; DeMarte \& Hartman, 1974; Gentner, 1977; McRoy \& McMillan, 1977; Twilley et al., 1977; Best \& Mantai, 1978; Carignan \& Kalff, 1979; Welsh \& Denny, 1979; Penhale \& Thayer, 1980; Carignan, 1982; Gabrielson et al., 1984; Brix \& Lingby, 1985; Smith \& Adams, 1986; Granéli \& Solander, 1988; Moeller et al., 1988).

After entering the root-rhizome, the phosphate is translocated to all portions of the plant. Certain investigators have also proposed a substantial excretion of $\mathbf{P}$ following translocation (McRoy \& Barsdate, 1970; McRoy et al., 1972; Gentner, 1977). Their findings stimulated interest in aquatic macrophytes as vectors of sediment-to-water $\mathbf{P}$ transfer ("P pump").

However, the work of McRoy \& Barsdate (1970), using a partitioning chamber to study translocation, has been subjected to criticisms (Welsh \& Denny, 1979; Denny, 1980 ) because their experiment incorporated no critical test for ${ }^{32} \mathrm{P}$ through the partition seal, as well as due to the excessive high ratio between the concentration in interstitial and overlaying water, i.e., 2000:25 $\mu \mathrm{g} \mathrm{P} \cdot \mathrm{l}^{-1}$ (Pellikaan \& Nienhuis, 1988).

Several later experiments carried out in Z. marina as well as in other aquatic macrophytes showed very low or zero P release to the water from healthy leaves (Bole \& Alan, 1978; Kirkman et al., 1979; Welsh \& Denny, 1979; Barko \& Smart, 1980; Penhale \& Thayer, 1980; Carignan \& Kalff, 1982; Gabrielson et al., 1984; Thursby \& Harlin, 1984; Brix \& Lyngby, 1985; Moeller et al., 1988). Thus, the literature provides conflicting data on foliar release by actively growing macrophytes.

The aim of this investigation was to study the uptake by root-rhizomes, acropetal translocation and possible excretion of $P$ in $Z$. noltii, and to examine the distribution of the translocated $P$ within the plant. This study was carried out to elucidate the role of $Z$. noltii in the cycling of $P$ between sediment and water as part of an intensive study into the functioning of a tidal estuarine ecosystem (Nienhuis \& Smaal, 1992). The research was done in June 1989 at the Delta Institute for Hydrobiological Research, Yerseke, The Netherlands (now Netherlands Institute of Ecology).

\section{Materials AND METHODS}

Vegetative plants of $Z$. noltii Hornem. were collected at Zandkreek, an extremely sheltered branch of the Oosterschelde estuary, Zeeland, The Netherlands $\left(4^{\circ} \mathrm{E} ; 52^{\circ} \mathrm{N}\right)$, with $\approx 300$ ha tidal flats and extensive $Z$. noltii beds $(\approx 100$ ha) (Vermaat et al., 1987).

The plants were harvested with a shovel, cleaned superficially of attached sediment and other debris and transported to the laboratory in plastic buckets filled with seawater. Dead and dying tissues were removed. Leaves were gently wiped to remove the epiphytes. Only the newest rhizome growth was retained; this consisted usually of two or three nodes, each with four to six well-developed roots. 
Plants were maintained, without sediment, in natural seawater in aerated 5-1 containers at $15^{\circ} \mathrm{C}$. Continuous light was supplied $\left(100 \mu \mathrm{E} \cdot \mathrm{m}^{-2} \cdot \mathrm{s}^{-1}\right)$ with cool white fluorescent light. The seawater was collected from the Oosterschelde estuary and filtered through Whatman GF/C filters. Plants were maintained under these conditions for 2-3 days before starting the experiments. A total of 180 plants of approximately the same size $[25 \pm 4 \mathrm{mg} \mathrm{dw}$ (leaves $9 \pm 3 \mathrm{~cm}$ long and rhizomes $3 \pm 0.5 \mathrm{~cm}$ )] were used in the experiments.

The acropetal translocation of $\mathrm{P}$ was studied in a two-compartment system which allowed the separation of the root-rhizomes portion from the leaves (Fig. 1). The upper and lower compartments consisted of a Plexiglas cylinder (length $8 \mathrm{~cm}$, diameter $6 \mathrm{~cm}$ each). The two compartments were divided by a black Plexiglas disk with six holes. The plants (six in each chamber) were positioned through the holes and sealed with silicone paste. The chambers (10), before any experimental work, were checked for leakage between compartments with sodium fluorescein dye. The dye was introduced in to either the leaf or the root compartment, and the opposite compartment was tested for the presence of the dye during the next 5 days with a spectrophotometer (Thursby \& Harlin, 1982). The daily analysis of the opposite compartment did not show signs of the dye, indicating that leakage did not occur.

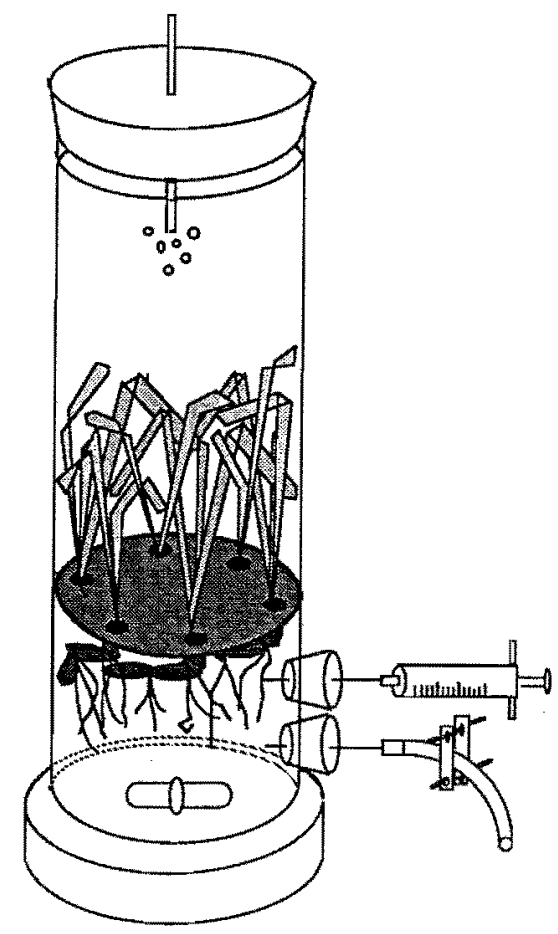

Fig. 1. Schematic drawing of two-compartment chambers used in incubations. 
Plants were placed in the chambers $3 \mathrm{~h}$ before the experiments and the enclosures were set on magnetic stirrers. The $\mathrm{O}_{2}$ concentration in the lower compartment was reduced by bubbling with $\mathrm{N}_{2}$, to simulate the sediment conditions. The root-rhizomes were in the dark. Initial concentration of phosphate in Oosterschelde water was $0.7 \mu \mathrm{M}$. At the initiation of the experiments, lower water was enriched with phosphate $\left(\mathrm{KH}_{2} \mathrm{PO}_{4}\right)$ and $25 \mu \mathrm{Ci}$ of carrier-free radioactive $\mathrm{P}\left(\mathrm{H}_{3}^{32} \mathrm{PO}_{4}\right)$ to obtain an initial phosphate concentration of $10 \mu \mathrm{M}$.

The influence of incubation time $(6,21,48,73$ and $99 \mathrm{~h})$ and light conditions (dark and $\left.150 \mu \mathrm{E} \cdot \mathrm{m}^{-2} \cdot \mathrm{s}^{-1}\right)$ in the uptake, translocation and foliar release of $P$ was investigated. All experiments, in triplicate, were run at constant temperature $\left(15^{\circ} \mathrm{C}\right)$ with aeration in the upper compartment and magnetic stirrers in the lower compartment. The plants were examined for physical deterioration during and after each experiment, showing no signs of damage.

At the end of each incubation time, water samples were removed from the upper compartment, the compartments drained and the plants removed. The root-rhizomes were separated from the leaves, and both were back-washed for $5 \mathrm{~min}$ in seawater free of phosphate. The plant material was then further dissected into roots, rhizomes and leaves (Leaves $1-3$, No. 1 was the youngest and No. 3 the oldest) and weighed. The activity of all samples was counted using liquid scintillation techniques (Beckman LS 5000 TD). The activity was corrected for background decay and quenching by using quenched standards with known activity.

Uptake and transfer rates in the plant tissue were calculated, assuming a constant specific activity during the experiments. In reality, the specific activity changes when the isotope taken up is diluted with the unlabeled material in the plant. Similar assumptions have been made in other studies (McRoy \& Barsdate, 1970; McRoy \& Goering, 1974; Wetzel \& Penhale, 1979; Penhale \& Thayer, 1980; Brix \& Lyngby, 1985).

\section{REsUlts}

The uptake of $\mathrm{P}$ in root-rhizomes of $Z$. noltii, translocation to leaves and foliar release during incubation times up to $99 \mathrm{~h}$ is shown in Fig. 2 (a-f).

The uptake of $\mathrm{P}$ by roots in the dark was not significantly different from the uptake in light (Kruskal-Wallis test, $p>0.05$ ) (Fig. 2a). Rhizomes accumulated higher amounts of $P$ in the dark (Kruskal-Wallis test, $p<0.1$ ) (Fig. 2b). The concentration of $P$ in the rhizomes showed an initial rapid increase (during the first $6 \mathrm{~h}$ ) and thereafter the concentrations remained nearly constant throughout the incubation period.

Acropetal movement of $P$ was recovered in the leaves after $6 \mathrm{~h}$, and this accumulation was lower in dark than in the light (Kruskal-Wallis test, $p<0.05$ ) and the difference increased at longer incubation times (Table I, Fig. 2c-e). After $99 \mathrm{~h}$ of incubation, $\approx 70 \%$ of the initial $\mathrm{P}$ in the water of the lower compartment 

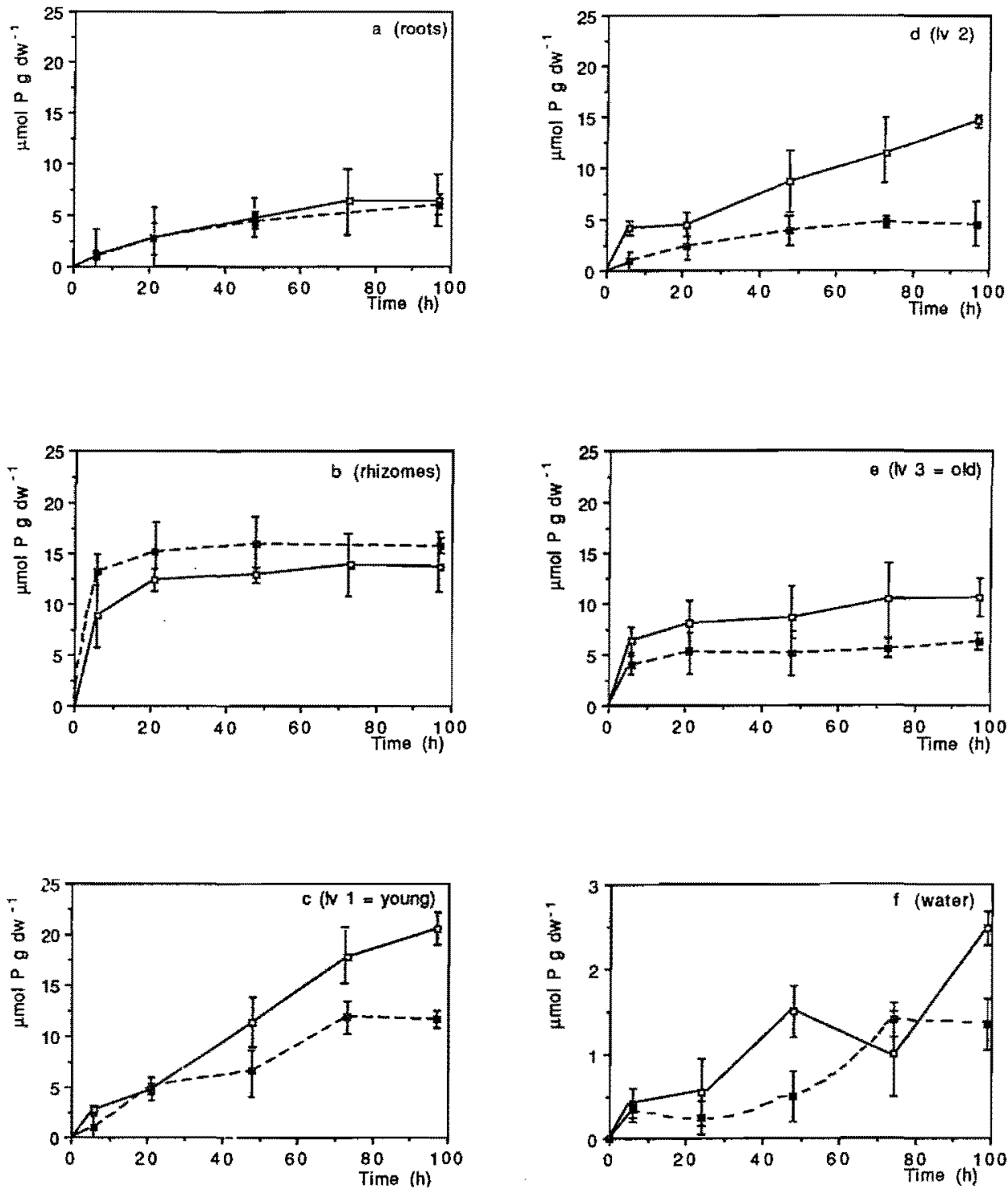

Fig, 2. Change of $P$ concentrations in roots (a) and rhizomes (b), translocation to leaves [Leaf 1 (c), Leaf 2 (d), Leaf 3 (e)] and release to upper water (f). Incubations were carried out in light (solid line, open squares) and in dark (dashed line, closed squares). ${ }^{32} \mathrm{P}$ was added to lower compartment. Bars, \pm sD of three replicates.

$\left(10 \mu \mathrm{M}=69 \pm 5 \mu \mathrm{mol} \mathrm{P} \cdot \mathrm{g} \mathrm{dw}^{-1}\right)$ was translocated to the leaves while this was only $33 \%$ in dark.

The pattern of foliar accumulation of $\mathrm{P}$ as well as the amount of this element recovered in the leaves were depending both on the age of the leaves and on the 
TABLE I

Percentages of $\mathbf{P}$ taken up, accumulated and released to upper water during 99-h incubation, either in light or dark conditions. Percentages refer to initial amount of $\mathrm{P}$ present in lower root-rhizome compartment.

\begin{tabular}{lccc}
\hline & Light (L) & Dark (D) & L/D \\
\hline Total P uptake & 98.8 & 62.7 & 1.6 \\
P accumulated in & & & \\
$\quad$ Roots & 9.4 & 8.2 & 1.1 \\
$\quad$ Rhizomes & 19.6 & 21.6 & 0.9 \\
$P$ translocated to Leaves & & 16.1 & 1.9 \\
1 & 30.1 & 6.2 & 3.4 \\
2 & 21.2 & 8.6 & 1.7 \\
3 & 14.6 & 2.0 & 2.0 \\
$P$ released to water & 4.0 & & \\
\hline
\end{tabular}

light-dark conditions. Thus, in the youngest leaves (Leaf 1), the highest levels of $P$ translocated from root-rhizomes was achieved. Older leaves (Nos. 2 and 3) accumulated lower amounts. This accumulation was two times higher in the light than in the dark throughout the incubation period. However, the youngest leaves showed the lowest initial accumulation rates after the initial $6 \mathrm{~h}$, and the oldest leaves the highest rates (Fig. 2c-e). Steady state in $\mathrm{P}$ concentration for the three types of leaves was earlier reached in the dark than in the light. Leaves 1 and 2 did not show signs of saturation with the translocated $P$ during the incubations in light.

The amount of translocated $P$ released by leaves after $99 \mathrm{~h}$ incubation was slightly higher in light $(4 \pm 0.9 \%$ of the initial phosphate concentration in the lower water) than in dark $(2 \pm 1.2 \%$ ) (Fig. 2 f, Table I). However, these quantities represented a small fraction of the total $P$ accumulated within the plants $(\approx 99.8 \%$ in the light and $62.7 \%$ in the dark) during this period.

\section{Discussion}

Although the uptake of $\mathrm{P}$ by roots and rhizomes was not affected by light conditions of the upper compartment, the acropetal translocation of this nutrient proceeded more rapidly in the light than in the dark. This fact is in agreement with the results of several studies carried out in Z. marina (McRoy \& Barsdate, 1970; Brix \& Lyngby, 1985), indicating that the uptake and posterior translocation are coupled to the metabolic activity of the plants (McRoy \& Barsdate, 1970). The amount of $\mathrm{P}$ translocated by $Z$. noltii constituted a maximum of $\approx 70 \%$ in the light and $33 \%$ in the dark of the total amount of $P$ taken up after an incubation time of $99 \mathrm{~h}$. McRoy \& Barsdate (1970) reported that $50 \%$ (in the light) and $13 \%$ (in the dark) of the total amount of $\mathrm{P}$ taken up by $Z$. marina, was translocated to the leaves after an incubation time of $50 \mathrm{~h}$. However, lower amounts were reported by Penhale \& Thayer (1980) and Brix \& 
Lyngby (1985) in the same species. The former authors found that $1.1-21.4 \%$ of the $\mathrm{P}$ absorbed in light by the underground parts was translocated to the leaves in $12 \mathrm{~h}$ incubation. Brix \& Lyngby (1985) reported a foliar translocation of $4 \%$ of the nutrient taken up by roots and rhizomes in an incubation time of $120 \mathrm{~h}$. In our study, the translocated $P$ was mainly accumulated in the youngest leaf (No. 1), which is the most actively growing part, acting as a natural sink for $P$ and $N$ (Welsh \& Denny, 1979; lizumi \& Hattori, 1982; Brix \& Lyngby, 1985; Pérez-Lloréns \& Niell, 1989; PérezLloréns et al., 1991).

A possible explanation of the differences observed in the $P$ translocation in the light and dark treatments should be on the basis of the available energy. Accumulative uptake of $\mathrm{P}$ by root cortical and rhizome cells must be followed by transfer to the xylem. Although a case has been described for a diffusive release of ions into the xylem vessels (Dunlop \& Bowling, 1971), most current evidence supports a release which is energy-dependent (Pitman, 1977). This energy source is ATP (Raven, 1974); in the dark this is supplied by oxidative phosphorylation and in the light, in addition, by the photophosphorylation. Thus, on this basis, it can explain the higher translocation rates, which proceed in light, but dark translocations are also found.

The higher translocation rates of $\mathrm{P}$ found in $Z$. noltii, compared with those reported in $Z$. marina by the authors mentioned above, could be due to the fact that the plants belong to different species, and to the fact that our experiments were carried out in summer when the total leaf growth of $Z$. noltii occurring at Zandkreek shows maximal values (Vermaat et al, 1987). Along these lines, Reimold (1972) and Twilley et al. (1977) reported higher acropetal movement of $P$ during summer, coinciding with the maximum primary productivity and biomass.

As was pointed out in the Introduction, the existing data concerning foliar release of $\mathbf{P}$ by growing aquatic macrophytes are conflicting and, to a certain extent, inconsistent. $Z$. marina has been widely studied in reference to its role in the cycling of $\mathbf{P}$ between sediment and water. McRoy \& Barsdate (1970) found that $33 \%$ of the total $\mathrm{P}$ taken up by the underground parts was released by leaves during an incubation time of $50 \mathrm{~h}$. McRoy et al. (1972) reported a net movement of $62 \mathrm{mg} \mathrm{P} \cdot \mathrm{m}^{-2} \cdot \mathrm{day}^{-1}$ from the sediment to the overlying water. Penhale \& Thayer (1980) and Brix \& Lyngby (1985) found a foliar release of $3.0 \pm 2.3 \%$ and $0 \%$, respectively, of the $\mathrm{P}$ absorbed by roots and rhizomes. Pérez-Lloréns \& Niell (1989) reported a foliar release in $Z$. noltii of $0.05 \mu \mathrm{mol} \mathrm{P} \cdot \mathrm{g}^{-1} \cdot \mathrm{h}^{-1}\left(7.1 \mathrm{mg} \mathrm{P} \cdot \mathrm{m}^{-2} \cdot \mathrm{day}^{-1}\right)$ in an in situ experiment. Granéli \& Solander (1988), in a review paper, supported the idea that the $P$ released to the water from actively growing macrophytes is, in general, low, reporting rates of $0.01-0.03 \mu \mathrm{mol}$ $\mathrm{P} \cdot \mathrm{g}^{-1} \cdot \mathrm{h}^{-1}$, which are in agreement with the values found in $Z$. noltii: $0.014 \mu \mathrm{mol}$ $\mathrm{P} \cdot \mathrm{g}^{-1} \cdot \mathrm{h}^{-1}$ in the dark $\left(2 \%\right.$ of the $\mathrm{P}$ taken up) and $0.025 \mu \mathrm{mol} \mathrm{P} \cdot \mathrm{g}^{-1} \cdot \mathrm{h}^{-1}$ in the light $(4 \%)$.

The idea of extrapolating the $P$ release rates obtained in the laboratory to the situation in the Oosterschelde estuary is just an attempt, and we are aware of the limitations. As Twilley et al. (1977) and Penhale \& Thayer (1980) pointed out, uprooting a 
plant will result in stress which may affect its processes; moreover, it is very difficult to simulate sediment-like conditions surrounding the belowground parts of the plant. In addition, other factors, such as the concentration of phosphate in the water column and the effect of emergence, temperature, etc., will affect these calculations.

The Zandkreek branch of the Oosterschelde estuary has a volume of $\approx 27 \times 10^{6} \mathrm{~m}^{3}$ and a total surface area of $10 \mathrm{~km}^{2}$. The above-ground vegetative biomass of $Z$. noltii varies from $<7 \mathrm{~g}$ in winter to $80-90 \mathrm{~g} \mathrm{dw} \cdot \mathrm{m}^{-2}$ in summer with a coverage of $20-60 \%$ over an area of 100 ha (Meulstee et al., 1986; Vermaat et al., 1987). On this basis, the amount of $\mathrm{P}$ "pumped" into the Zandkreek by this species would range from $0.2 \mathrm{nM} \cdot$ day $^{-1}$ (in a winter situation with a photoperiod of $10 \mathrm{~L}: 14 \mathrm{D}$ and a coverage of $20 \%$ ) to $9.2 \mathrm{nM} \cdot$ day $^{-1}$ in summer $(14 \mathrm{~L}: 10 \mathrm{D}$ and a coverage of $60 \%$ ). This release is not relevant compared with the quantities of $\mathrm{P}$ leached and mineralized during the decay of plants (Granéli \& Solander, 1988). Kirkman et al. (1979) and Pellikaan \& Nienhuis (1988) pointed out that the high $\mathrm{P}$ concentrations (released during leaching) are only a temporary phenomenon in places where large seagrass accumulations are present during certain times of the year.

\section{ACKNOWLEDGEMENTS}

This work has been supported by the Spanish Commission for Science and Technology (Project PB-86-0677) and by fellowship of the "Plan Nacional de Formación de Personal Investigador/87 Plan Nacional". The first author thanks the Director of the Netherlands Institute of Ecology, Yerseke, for working facilities.

\section{REFERENCES}

Barko, J.W. \& R.M. Smart, 1980. Mobilization of sediment phosphorus by submersed freshwater macrophytes. Freshwater Biol., Vol. 10, pp. $229-238$.

Best, M.D. \& K. Mantai, 1978. Growth of Myriophyllum: sediment or lake water as the source of nitrogen and phosphorus. Ecology, Vol. 59, pp. 1075-1080.

Bole, J.B. \& J.R. Allan, 1978. Uptake of phosphorus from sediment by aquatic plants, Myriophyllum spicatum and Hydrilla verticillata. Water Res., Vol. 12, pp. 353-358.

Bristow, J. M. \& M. Whitecombe, 1971. The role of the roots in the nutrition of aquatic vascular plants. Am. J. Bot., Vol. 58, pp. $8-13$.

Brix, H. \& J. E. Lyngby, 1985. Uptake and translocation of phosphorus in eelgrass (Zostera marina L.). Mar. Biol., Vol. 90, pp. 111-116.

Carignan, R. \& J. Kalf, 1979. Quantification of the sediment phosphorus available to aquatic macrophytes. J. Fish. Res. Bd Can., Vol. 36, pp. 1002-1005.

Carignan, R., 1982. An empirical model to estimate the relative importance of roots in phosphorus uptake by aquatic macrophytes. Can. J. Fish. Aquat. Sci., Vol. 39, pp. 243-247.

Carignan, R. \& J. Kalf, 1982. Phosphorus release by submerged macrophytes: significance to epiphyton and phytoplankton. Limnol. Oceanogr., Vol. 27, pp. 419-427.

Delgado, O., 1985. Aproximación al estudio del ciclo del fósforo en las praderas de fanerógamas marinas: los vegetales. M.S. thesis, University of Barcelona, $86 \mathrm{pp}$. 
DeMarte, J. A. \& R. T. Hartman, 1974. Studies on absorption of ${ }^{32} \mathrm{P},{ }^{59} \mathrm{Fe}$ and Ca by water milfoil (Myriophyllum exalbescens, Fernald). Ecology, Vol. 55, pp. 188-194.

Den Hartog, C., 1970. The seagrasses of the world. Verh. K. Ned. Akad. Wet. Afd. Naturkd. Reeks 2, Vol. 59 (1), pp. $1-275$.

Denny, P., 1972. Sites of nutrient absorption in aquatic macrophytes. J. Ecol, Vol. 60, pp. 819-829.

Denny, P., 1980. Solute movement in submerged angiosperms. Biol. Rev, Vol. 55, pp. 65-92.

Dunlop, J. \& D.J.F. Bowling, 1971. The movement of ions to the xylem exudate of maize roots. 1. Profiles of membrane potential and vacuolar potassium activity across the root. J. Exp. Bot., Vol. 22, pp. $434-444$.

Gabrielson, J.O., M.A. Perkins \& E. B. Welsh, 1984. The uptake, translocation and release of phosphorus by Elodea densa. Hydrobiologia, Vol. 111 , pp. 43-48.

Gentner, S. R., 1977. Uptake and transport of iron and phosphate by Vallisneria spiralis L. Aquat. Bot, Vol. 3, pp. 267-272.

Granéli, W.\& D. Solander, 1988. Infuence of aquatic macrophytes on phosphorus cycling in lakes. $H_{y-}$ drobiologia, Vol. 170 , pp. 245-266.

Iizumi, H. \& A. Hattori, 1982. Growth and organic production of eelgrass (Zostera marina L.) in temperate water of the Pacife coast of Japan. III. The kinetics of nitrogen uptake. Aquat. Bot., Vol. 12, pp. $245-256$.

Jacobs, R.P.W.M., 1982. Reproductive strategies of two seagrass species (Zostera marina and $Z$. noltii) along West European coasts. In, Studies on aquatic vascular plants, edited by J.J. Symoens et al., Royal Botanical Society of Belgium, Brussels, pp. 150-155.

Jacobs, R.P.W.M. \& W. H.T. Huisman, 1982. Macrobenthos of some Zostera beds in the vicinity of Roscoff (France) with special reference to relations with community structure and environmental factors. Proc. Kon. Ned. Akad. Wet., Vol. 85, pp. 335-356.

Jacobs, R. P.W.M., H.H. Hegger \& A. Ras-Willems, 1982. Seasonal variations in the structure of a Zostera community on tidal flats in The S.W. Netherlands, with special reference to the benthic fauna. Proc. Kon. Ned. Akad. Wet., Vol. 86, pp. 347-375.

Jacobs, R.P.W.M., T. M.P.A. Noten \& E. Claasen, 1983. Population and growth characteristics of the seagrass Zostera noltii Hornem. in the Dutch Wadden Sea. Proc. Int. Symp. Aquat. Macrophytes Nijmegen, pp. $95-100$.

Jiménez, C., F.X. Niell \& P. Algarra, 1987. Photosynthetic adaptation of Zostera noltii Hornem. Aquat. Bot., Vol, 29, pp. 217-226.

Jiménez, C., P. Algarra, J, L. Pérez-Lloréns \& F.X. Niell, 1991. Adaptación fotosintética en Zostera noltii Hornem. y Zostera marina L. Act. V Simp. Iber. Estud. Bentos Mar., Vol. 1, pp. 333-350.

Kirkman, H., F.B. Griffiths \& R. R. Parker, 1979. The release of reactive phosphate by Posidonia australis seagrass community. Aquat. Bot, Vol. 6, pp. 329-337.

McRoy, C.P. \& R. J. Barsdate, 1970. Phosphate absorption in eelgrass. Limnol. Oceanogr., Vol. 15, pp. 6-13.

McRoy, C.P., R.J. Barsdate \& M. Nerbert, 1972. Phosphorus cycling in an eelgrass (Zostera marma) ecosystem. Limnol. Oceanogr., Vol. 17, pp. 58-67.

McRoy, C.P. \& J.J. Goering, 1974. Nutrient transfer between the seagrass Zostera marina and its epiphytes. Nature, Vol. 258, pp. 173-174.

McRoy, C. P. \& C. McMillan, 1977. Production ecology and physiology of seagrasses. In, Seagrass ecosystems: a scientific perspective, edited by C. P. McRoy \& C. Helfferich, Marcel Dekker, New York, pp. 53-88.

Meulstee, C., P.H. Nienhuis \& H.T.C. Van Stokkom, 1986. Biomass assessment of estuarine macrophytobenthos using aerial photography. Mar. Biol, Vol. 91, pp. 331-335.

Moeller, R. E. J.M. Burkholder \& R.G. Wetzel, 1988. Significance of sedimentary phosphorus to a rooted submersed macrophyte (Najas fexilis (Willd.) Rostk. and Schmidt) and its algal epiphytes. Aquat. Bot, Vol. 32 , pp. 261-281.

Nienhuis, P.H. \& A.C. Smaal, 1992. The Oosterschelde estuary, a case study of a changing ecosystem; an introduction. Hydrobiologia, in press. 
Patriquin, D., 1972. The origin of nitrogen and phosphorus for growth of the marine angiosperm Thalassia testudinum. Mar. Biol., Vol. 15, pp. 35-46.

Pellikaan, G.C.\& P.H. Nienhuis, 1988. Nutrient uptake and release during growth and decomposition of eelgrass Zostera marina L., and its effects on the nutrient dynamics of Lake Grevelingen. Aquat. Bot., Vol. 30, pp. 189-214.

Penhale, P.A.\& G.N. Thayer, 1980. Uptake and transfer of carbon and phosphorus by eelgrass (Zostera marina L.) and its epiphytes. J. Exp. Mar. Biol. Ecol, Vol. 42, pp. 113-123.

Pérez, M. \& J. Camp, 1986. Datos preliminares sobre distribución y biomasa de las fanerógamas marinas de las bahías del delta del Ebro. Inv. Pesq., pp. 519-530.

Pérez, M., 1989. Fanerógamas marinas en sistemas estuáricos: Producción, factores limitantes y algunos aspectos del ciclo de nutrientes. Ph.D. thesis, University of Barcelona, $244 \mathrm{pp}$.

Pérez-Lloréns, J.L. \& F.X. Niell, 1989. Emergence and submergence effects on the distributional pattern and exchange of phosphorus in the seagrass Zostera nolii Hornem. Sci. Mar., Vol. 53, pp. 497-503.

Pérez-Lloréns, J. L., 1991. Estimaciones de biomasa y contenido interno de nutrientes, ecofisiología de incorporacion de carbono y fosfato en Zostera noltii Hornem. Ph.D. thesis, University of Málaga, $168 \mathrm{pp}$.

Pérez-Lloréns, J. L., M. Muchtar, P. H. Nienhuis \& F.X. Niell, 1991. Particulate organic carbon, nitrogen and phosphorus in roots, thizomes and differently aged leaves of Zostera noltii Hornem. in Oosterschelde (SW Netherlands). Bot. Mar, Vol. 34, pp. 319-322.

Pirc, H. \& B. Wollenweber, 1988. Seasonal changes in nitrogen, free amino-acids, and C:N ratio in Mediterranean seagrasses. Mar. Ecol., Vol. 9, pp. 169-179.

Pitman, M.G., 1977. Ion transport into the xylem. Annu. Rev. Plant. Physiol, Vol. 28, pp. 71-88.

Raven, J.A., 1974. Energetics of active phosphate influx in Hydrodictyon africanum. J. Exp. Bot., Vol. 25, pp. 221-229.

Reimold, R. J., 1972. The movement of phosphorus through the salt marsh cord grass, Spartina alternifora Loisel. Limnol. Oceanogr, Vol. 17, pp. 606-611.

Smith, C.S. \& M.S. Adams, 1986. Phosphorus transfer from sediments by Myriophyllum spicatum. Limnol. Oceanogr., Vol. 31, pp. 1312-1321.

Thursby, G. B. \& M.M. Harlin, 1982. Leaf-root interaction in the uptake of ammonia by Zostera marina. Mar. Biol, Vol. 72, pp. 109-112.

Thursby, G.B. \& M. M. Harlin, 1984. Interaction of leaves and roots of Ruppia maritima in the uptake of phosphate, ammonia and nitrate. Mar. Biol., Vol. 83, pp. 61-67.

Twilley, R.R., M.H. Brindson \& G.J. Davis, 1977. Phosphorus absorption, translocation and secretion in Nuphar luteum. Limnol. Oceanogr., Vol. 22, pp. 1022-1032.

Vermaat, J. E., M. J. M. Hootsmans \& P. H. Nienhuis, 1987. Seasonal dynamics and leaf growth of Zostera noltii Hornem., a perenni intertidal seagrass. Aquat. Bot., Vol. 28, pp. 287-299.

Welsh, R.P.H. \& P. Denny, 1979. The translocation of ${ }^{32} \mathrm{P}$ in two submerged aquatic angiosperm species. New Phytol, Vol. 82, pp. 645-656.

Wetzel, R.G. \& P.A. Penhale, 1979. Transport of carbon and excretion of dissolved organic carbon by leaves and root/rhizomes in seagrasses and their epiphytes. Aquat. Bot., Vol. 6, pp. 149-158. 
. 
